\title{
Description of Some Aquatic Insect Genera in Greater Zab River Branches, North of Iraq
}

\author{
Shelan Mustafa Khudhur* and Yahya Ahmed Shekha \\ Department of Health and Environmental Science, College of Science, Salahaddin University, Erbil, \\ Kurdistan Region-Iraq
}

\begin{tabular}{ll}
\hline \multicolumn{1}{c}{ Article's Information } & \multicolumn{1}{c}{ Abstract } \\
\hline Received: & Aquatic insects samples were collected from 6 sites along the Greater Zab River \\
01.09 .2021 & in the northern Iraq from Duhok and Erbil governorates over 12 months during \\
Accepted: & September 2016 to August 2017, which belong to seven orders (Ephemeroptera, \\
21.10 .2021 & Plecoptera, Trichoptera, Odonatan, Diptera, Coleoptera, and Megaloptera). \\
Published: & Clustering mitochondrial DNA cytochrome c oxidase and 16S rDNA genes, \\
$31-12-2021$ & morphological keys, and matches in the Barcode of Life Database, we identified \\
Keywords: & 24 species return to 7 orders and 12 families, as indicated in the results. The \\
Aquatic insects & reported species were: Ephemeroptera 5 members of the family Heptageniidae \\
Morphology & (Maccaffertium meririvulanum, Raptoheptagenia cruentata, Ecdyonurus dispar, \\
Mitochondrial DNA cytochrome c & Anepeorus rusticus, Stenonema femoratum), 1 Ephemerellidae (Seratella ignita), \\
oxidase & 1 Arthropleidae (Arthroplea bipunctata), 6 Baetidae (Baetis alpinus, Baetis \\
$16 \mathrm{~S}$ rDNA gene & braaschi, Baetis noa, Baetis harrisoni, Iswaeon anoka, Heterocloeon amplum), 1 \\
& member for each of Diptera, Coleoptera, Megaloptera and Odonatan orders, while \\
& Plecoptera 2 members Leuctridae (Leuctra hippopoides, Leuctra inermis) and \\
& Tricoptera 4 members 3 Hydropsychidae (Leptonema albovirens, Hydropsyche \\
& simulans, Arctopsyche irrorate), 1 Hydroptilidae (Ochrotrichia tenuata). Most of \\
& these recorded species and genera were mentioned for the first time and represent \\
& new records in Iraq. Presence and distribution of identified species varied between \\
& studied sites, as a result of differences in biogeographical and physical conditions. \\
\hline
\end{tabular}

DOI: 10.22401/ANJS.24.4.10

*Corresponding author: shelan.khudhur@su.edu.krd

\section{Introduction}

One of the most common approaches for assessing the effects of stresses on the ecological conditions of aquatic ecosystems and water quality monitoring is to studying benthic macroinvertebrate populations [1].

Aquatic macroinvertebrates are critical to ecosystem functioning through regulation of many essential top down and bottom-up ecosystem processes such as energy translocation, nutrient flow, and detrital decomposition, and act as excellent bioindicators of stream health because of their sensitivity to pollution [2] and wide variation of response to pollutants [3-5]. The disappearance or loss of biodiversity in macroinvertebrate communities could be easily assigned to anthropogenic pressure [6] integrating the impacts of multiple chemical and physical stressors, including land-use types [7].

Mayflies, stoneflies and caddisflies (Ephemeroptera, Plecoptera and Trichoptera) are prominent representatives of aquatic macroinvertebrates widely used as indicator species for water quality and environmental assessment. Though, clear morphological identification of EPT species, particularly their immature life stages, is difficult but essential task [8].
Nowadays, DNA barcoding and DNA sequencing in certain gene loci are used as an identification method to provide a valuable way of understanding species diversity in many populations of taxonomically complicated studies and confirming the taxonomy of poorly recognized communities $[9,10]$.

Within northern Iraq (Iraqi Kurdistan Region), the water resource from Greater Zab River catchment is under population pressure and used for drinking, domestic, agricultural and industrial supplies [11,12]. This study aimed to use the findings from an ecological perspective as bio-indicators for the Greater Zab Tributary.

\section{Materials and Method}

2.1 Study area:

In the present study, a total of 6 sites for sampling and collecting of aquatic insects were selected along the Greater Zab River within Erbil and Duhok Province as follows (Figure 1). 


\section{Al-Nahrain Journal of Science}

ANJS, Vol.24 (4), December, 2021, pp. 68-78

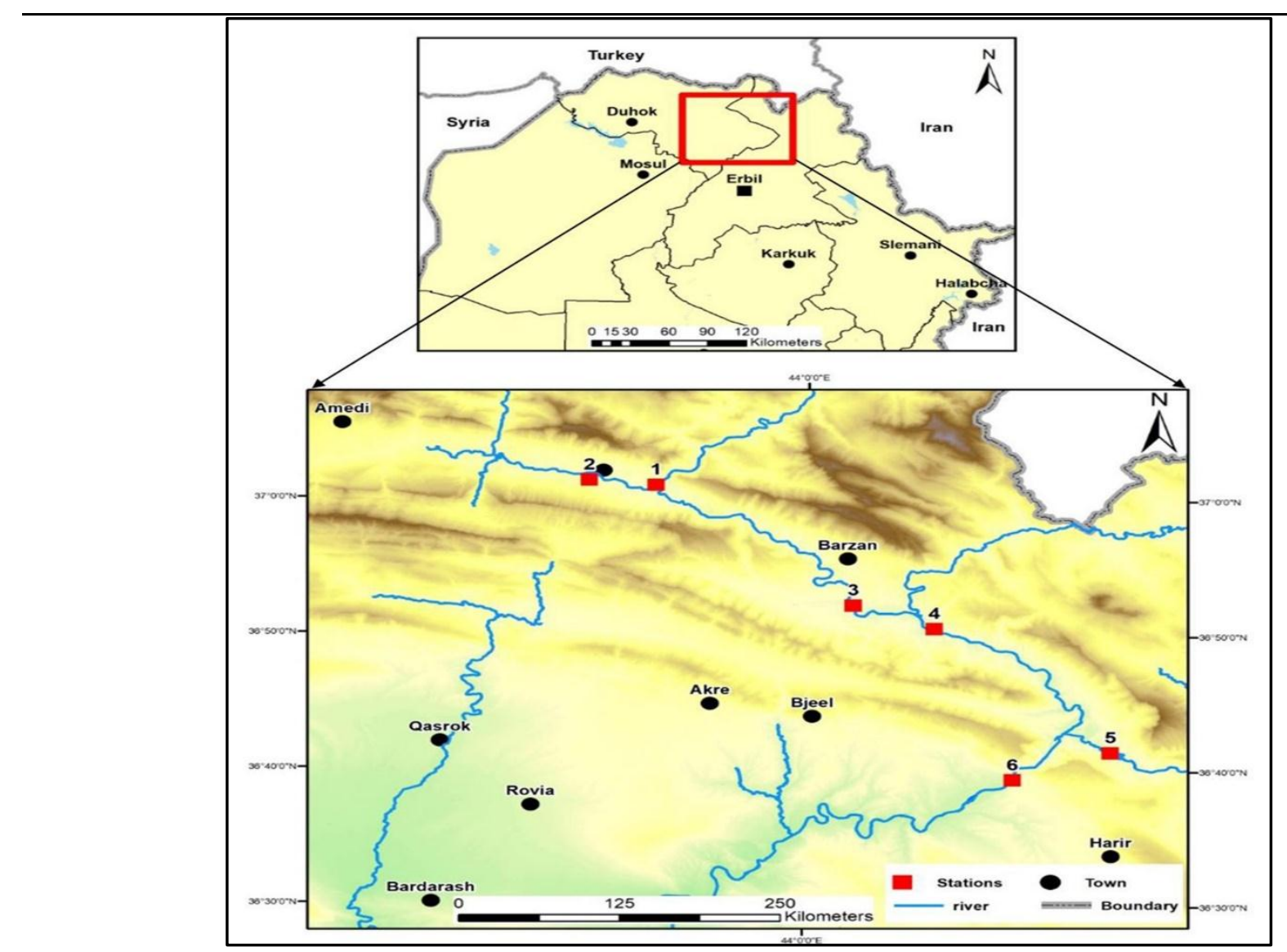

Figure 1. Shows Map of: A- Northern Part of Iraq- studied area, B- Sampling Sites of Greater Zab River.

\subsection{Aquatic Insect sampling:}

Samples of aquatic insects from sediments, rocks and fallen leaves were collected by using Surber sampler in each sampling sites monthly for 12 months from six different studied sites from September 2016 to August 2017. The samples were washed by river water using sieves with $(500$ $\mu \mathrm{m}$ mesh). After being transported to the laboratory, benthic macroinvertebrates and insect samples were separated from the substratum materials, washed with water and isolated to the main taxonomic groups. These were first held in the field in $4 \%$ formaldehyde solution [13]. Then, samples were placed in 95\% ethyl alcohol solution for the molecular identification process [10].

\subsection{Morphological examination:}

Compound and dissecting microscope were used for identification and counting of aquatic insect depending on the following key references: [14-21]. The results were expressed as individual $/ \mathrm{m}^{2}$.

\subsection{Molecular evaluation:}

After morphological recognition, the specimens were processed individually for molecular analyses at Ankara University's Department of Biological Sciences' molecular biology laboratory (Ankara, Turkey).

Tissue samples were obtained from the thorax, abdomen and if the sample is small, whole organisms were used.
Cetyl Trimethyl Ammonium Bromide (CTAB) method [22] was followed to extract the nucleic acids and the details were as follows:- specimen was homogenized in $300 \mu \mathrm{l}+$ $50 \mu \mathrm{B} \mathrm{B} \mu \mathrm{E}$ mixed and incubated at $65 \mathrm{c}$ for $1 \mathrm{hr}$.; then $250 \mu \mathrm{l}$ C: IAA was added, mixed well and centrifuged on 13000 $\mathrm{rpm}$ for $15 \mathrm{~min}$. the supernatant was taken and added $500 \mu \mathrm{l}$ isopropanol and incubated for $30 \mathrm{~min}$ at $-80^{\circ} \mathrm{C}$. then centrifuged for $10 \mathrm{~min}$ at $13000 \mathrm{rpm}$. a pellet was washed with pure ethanol and dissolved the dried pellet with $50 \mu \mathrm{l}$ TE buffer of extraction buffer (100 mM Tris- $\mathrm{HCl}(\mathrm{pH} 8)$, $100 \mathrm{mM}$ EDTA (pH 8), $100 \mathrm{mM}$ Na-Phosphate buffer (pH $8), 250 \mathrm{mM} \mathrm{NaCl}, 2 \pm \%$ CTAB) by a sterile hand pestle. After incubating at $65^{\circ} \mathrm{C}$ at water bath, equal volume of chloroform-isoamyl alcohol (24:1) mixture was added, mixed properly and centrifuged at $12,000 \mathrm{rpm}$ for $15 \mathrm{~min}$ at $4^{\circ} \mathrm{C}$. The clear aqueous phase was separated in a sterile microcentrifuge tube and 0.6 volume of room temperature isopropanol was added, mixed and incubated at $-80{ }^{\circ} \mathrm{C}$ for 30-45 $\mathrm{min}$ to allow precipitation of the DNA. After incubation, centrifugation was carried out at $13,000 \mathrm{rpm}$ for $10 \mathrm{~min}$ at $4^{\mathrm{C}} \mathrm{C}$. The resulting pellet was then washed with $70 \%$ chilled ethanol twice and dried. Dried pellets were dissolved in TE buffer and stored at $-20{ }^{\circ} \mathrm{C}$ for further applications. DNA quality and quantity were measured using a Nano VueTM Plus spectrophotometer.

PCR amplification was conducted using two universal primers. the primer pair LC01490 (5'- 


\section{Al-Nahrain Journal of Science}

ANJS, Vol.24 (4), December, 2021, pp. 68-78

\begin{tabular}{lr}
\hline GGTCAACAAATCATAAAGA & TATTGG-3') and \\
HC02198 & (5'-TAAACTTCAG
\end{tabular}

GGTGACCAAAAAATCA-3') to amplify a 658- base-pair fragment of COI $[23,24]$. The 16S rRNA gene was amplified using the primer pair 16Sa (F) 50GCCTGTTTATCAAAAACAT-30 and 16Sb (R) 50CTCCGGTTTGAACTCAGATCA-30 [25].

The amplifications were performed on a Techne TCPLUS thermocycler, according to the following conditions: initial denaturation at $94{ }^{\circ} \mathrm{C}$ for 2 min, followed by 7 cycles at $94{ }^{\circ} \mathrm{C}$ for $30 \mathrm{sec}$.; $45^{\circ} \mathrm{C}$ for $30 \mathrm{sec}$.; and 72 ${ }^{\circ} \mathrm{C}$ for $45 \mathrm{sec}$.; followed by 28 cycles at $94{ }^{\mathrm{C}} \mathrm{C}$ for $30 \mathrm{sec}$.; 48 ${ }^{\circ} \mathrm{C}$ for $30 \mathrm{sec}$.; and $72{ }^{\circ} \mathrm{C}$ for $45 \mathrm{sec}$.; completing the reaction with a final extension cycle at $72{ }^{\circ} \mathrm{C}$ for $7 \mathrm{~min}$, for the $16 \mathrm{~S}$ rRNA gene [26].

PCR products were checked by Agarose gel electrophoresis (Prono). PCR products were sent to BM Labosis for sequencing service. Sequences obtained were evaluated by Chromas and Clustal $\mathrm{X}$ and analyzed with MEGA software.

\subsection{Data analysis:}

Sequencher (2011) was used to modify and assemble the forward and reverse sequences, using the Clustal W algorithm with default parameters [25].

\section{Results and Discussion}

Throughout the studied period, a total of 7 macroinvertebrate orders (aquatic insects) were encountered in Greater Zab River. Common taxonomic groups found in the river including Ephemeroptera, Plecoptera, Trichoptera, Odonatan, Diptera, Coleoptera and Megaloptera. These taxonomic groups comprised 12 families sampled and identified based on morphological characteristics and molecular markers. The most dominated order was Ephemeroptera followed by Trichoptera, then Plecoptera and followed by Diptera, Odonata, Megaloptera and Coleoptera. The most dominant family of Ephemeroptera was Heptageniidae and Baetidae, each represented by ten species. This is because; mayflies have a diverse range of amphinotic insects worldwide associated with liquid freshwater especially small rocky streams with fewer large fish $[27,28]$. Moreover, Caenidae the family represented by six species followed by Ephemerellidae represented by two species.

The number of macro invertebrate insect families mentioned in this investigation were not reported previously from studied conducted by [29-31] at Greater Zab River.

Generally, few studies were dealing with aquatic insects are available compared to other studies in Iraq; therefore, the following species of aquatic insects identified in this study were not mentioned in previous studies conducted in Iraq and are regarded as a new record in Iraq. The description and measurement of the newly recorded taxa are summarized as follows:

\section{Phylum: Arthropoda \\ Class: Insecta \\ Order: Ephemeroptera \\ Family: Heptageniidae \\ Maccaffertium meririvulanum (Carle \& Lewis, 1978):}

Nymphs 10-16 mm; 7-10 spine-like setae on maxillary crown; claws without denticles; posterolateral projections absent anterior to segment 6; terga 5 and either 7-8, or 7-9 each with distinct V-shaped pale mark; ventrally pale. Gills on segment 1-6 with apex truncated, three well developed caudal filaments. A very intolerant, small mountain stream species.

Raptoheptagenia cruentata (Walsh, 1863):

Gills ventral, lamellae slender with numerous gill filaments radiating out, gills 1-7 enlarged and meet beneath the abdomen.

Ecdyonurus dispar (plate 1) (Curtis, 1834):

Head with a few scattered black spots near anterior margin, abdominal terga usually without distinct contrasting color patterns, gills lateral in position, lamellae broad, gill filaments variable, three well-developed caudal filaments, gills on segment 7 without filliform portion, claws with distinct denticles, caudal filaments with welldeveloped interfacing setae.

Anepeorus rusticus (McDunnough, 1925):

Nymph with only two well-developed caudal filaments, terminal filaments absent, interfacing setae on the caudal filaments. gills 1 and 2 inserted ventrally, gills 3 ventral or ventro-laterally, mouth part modified for predation, claws with a single tooth and no denticles, head and thorax without paired dorsal tubercle, abdomen with very small dorsal tubercle, femora broad, flattened, legs with long, fine setae. Stenonema femoratum (plate 2) (Say, 1823):

Nymphs 8-12 mm; body and head distinctly flattened; abdominal gills 1-6 with apex rounded. Mostly dark brown with anteromedial pale spots. Abdominal sterna each with pair of lateral dark spots. Three caudal filaments.

\section{Family: Ephemerellidae}

Seratella ignita (plate 3) (Poda, 1761):

Nymphs body $5.5-8.5 \mathrm{~mm}$, easily recognized by the alternate light and dark bands and whorls of spines at apex of segments on the caudal filaments, and the backwardlydirected projections on either side of the mid-dorsal line of the abdomen. Paired dorsal tubercles on posterior margin of terga 4-7. Posto-lateral extensions on tergum 9 rarely extend beyond segment 10 .

\section{Family: Arthropleidae \\ Arthroplea bipunctata (McDunnough, 1924):}

The second segment of maxillary palpi is longer than the head is broad. Claws much shorter than tarsi, claws without a tooth, but with three or more subapical denticles. gills heartshaped, lateral in position, lamellae broad. Posterior margin of terga with a row of long slender spines. 


\section{Al-Nahrain Journal of Science}

ANJS, Vol.24 (4), December, 2021, pp. 68-78

Family: Baetidae

Baetis alpinus (Pictet, 1843):

Body length 7-10 mm. body greenish brown. Pro- and mesonotum with dark spots and strips. Legs darkened near the apex of femur and tibia, femora with a narrow dark brownish strip along margin. Posterior the margin of femora with numerous long and pointed bristles.

Baetis braaschi (Zimmermann, 1980):

Body length 7-8.5 mm. thorax yellowish brown to brown, with indistinct markings on pronotum. Meso- and metanotum with brown longitudinal strips and small lateral spots. Legs uniformly light yellowish- brown. Outer margin of femora with short apically rounded bristles, tarsal claws with 8-13 teeth. Gills 3-5 strongly asymmetric, stout bristles along outer margin absent. Paracercus 2/3-3/4 of cerci length.

Baetis noa (Yanai \& Gattolliat, 2018):

General color brown, body size 4.7-5.8 mm. Head brown with ecru spots on frons, around compound eyes and around antennal bases, labrum light brown. Thorax brown with a few pale marks but with no clear pattern. Legs whitish, with light brown spot on dorsal femora, usually with proximal and distal brownish marks on femora and tibiae. On all terga a pair of median dark dots are occasionally present. Gills milky, margins dark brown. Cerci and median caudal filament ecru without bands or patterns. Median caudal filament at least 1/2 length of cerci. Gill margins with short spines. Distal margin of terga with many short spatulas.

Baetis harrisoni (plate 4) (Barnard, 1932):

All small minnow mayflies are characterized by a small spindle-shaped body with 6 or 7 pairs of gills on either side of the abdomen, consisting of a single oval plate without basal tufts. The long antennae are one of the most apparent features of this group which are longer than the head. Their color varies from light sand to dark brown depending on the environmental conditions they are exposed to.

Iswaeon anoka (plate 5) (Daggy, 1945):

The length of the body varies between around 4.0-8.0 $\mathrm{mm}$. hind wing pads are absent. Cerci with a central dark band or three lighter narrower bands. Abdominal segment 5 without dark pigment encircling the segment. Pale stripe running longitudinally in the center of abdominal tergites, claws with an extremely reduced second row of denticles.

Heterocloeon amplum (Traver, 1932):

Body length 7-9 mm, body not flattened dorsoventrally. Terminal filaments reduced, hind wing pads present. segment 2 of labial palps with a developed projecting corner, abdominal tergal scale like setae present. Fore coxa without filamentous gill.

\section{Order: Diptera}

\section{Family: Simuliidae}

Simulium venustum (plate 6) (Say, 1823):

Head capsule usually complete and fully exposed, head showing distinct constrictive separation from the thorax. prothorax with 1 proleg or a pair of prolegs head capsule with a pair of folding labral fans dorso-laterally abdomen 5-
8 swollen, posterior segment terminating in a ring of radiating rows of hooks labral fans present, head with sides parallel anal seclerite with posterior arms, antenna with proximal articles, hypostoma with the apex of median tooth extended anteriorly.

Order: Coleoptera

Family: Gyrinidae

Orectochilus villosus (plate 7) (Müller, 1776):

Legs may be small with 3-6 defined segments, legs 5 segment, tarsi 2 claws, abdomen with 2 pairs of stout terminal hook on segment 10, abdominal segments 1-9 bearing lateral gills, body long, greyish color, anterior fronto-clypeal margin truncate in the middle.

\section{Order: Megaloptera}

Family: Corydalidae

Nigrania serricarnis (plate 8) (Say, 1824):

The larvae are slightly flattened, up to $33 \mathrm{~mm}$ length. The head antero-laterally possesses 4-5 segmented setaceous antennae and eyes. The mouthparts chewing type. The prothorax is heavily sclerotized with the pronotum relatively large and sub-rectangular. Each thoracic segment bears a pair of well-developed legs consisting of 5 segments. Tarsi are 1-segmented and at the apex bear a pair of hook-shaped tarsal claws. S-shaped body with lateral abdominal filaments without ventral gill tufts.

\section{Order: Plecoptera}

Family: Leuctridae

Leuctra hippopoides (plate 9) (Kacanski \& Zwick, 1970):

Elongate narrow nymphs, without ventral gill tufts on thorax, gills, not conical, the sterna not overlapping, paraglossa and glossa produced forward in the same distance, $2^{\text {nd }}$ tarsal segment shorter than 1 st, midline of wing pads parallel, no cervical gills, at most abdomen 1-7 separated by membranous pleural fold, abdominal segments cylindrical, hind wing pads longer than wide, abdominal terga with a posterior fringe of short or long setae, and its last few segments with 2-4 long setae, more than 12 bristles on each side of the pronotum.

\section{Leuctra inermis (plate 10) (Kempny. 1899):}

Elongate nymph's length from 6-9 mm. without ventral gill tufts on the thorax, gills, not conical, the sterna not overlapping, paraglossa and glossa produced forward in the same distance, $2^{\text {nd }}$ tarsal segment shorter than 1 st, midline of wing pads parallel, extend hind legs reach far short of ab tip. Abdomen parallel sided, abdominal terga with a posterior fringe of short or long setae, and it is the last few segments with 2-4 long setae, abdominal terga 2-10 each with one pair of long dorsolateral bristles.

\section{Order: Odonata}

Suborder: Zygopteraa

Family: Lestidae

Lestes inaequalis (plate 11) (Walsh, 1862):

Nymph slender, head wider than thorax and abdomen, 3 long caudal gills, 1st antennal segment not so elongate, prementum with a deep open median cleft, lateral caudal gills 


\section{Al-Nahrain Journal of Science}

ANJS, Vol.24 (4), December, 2021, pp. 68-78

triangular in cross section, pre-mentum stalked and spoon shaped, a movable hook of each palpal lobe with 2 or 3 setae, distal margin of each palpal lobe divided into 4 processes.

\section{Order: Trichoptera}

Family: Hydropsychidae

\section{Leptonema albovirens (Walker, 1852):}

Larvae construct cylindrical portable cases, anal claw with stout apical hook, metanotum entirely covered by sclerite, abdomen with ventrolateral rows of gills, a tuft of long setae at anal proleg, genae touching ventrally, separating ventral apotome into anterior and posterior parts, posterior ventral apotome no longer than broad, abdominal gills with up to 40 filaments, fore trochantins never forked, tibia and tarsus of each prothoracic leg lacking dense steal fringe, dorsum of head convex and without carina.

\section{Hydropsyche simulans (plate 12) (Ross, 1938):}

Larvae construct cylindrical portable cases, anal claw with stout apical hook, metanotum entirely covered by sclerite, abdomen with ventrolateral rows of gills, a tuft of long setae at anal proleg, genae ventrally, separating apotome into anterior and posterior parts or inconspicuous abdominal gills with about 10 filaments near apex of central stalk, fore trochantins usually forked, abdominal sternum viii with pair of sclerite, prosternum with pair of large sclerites in the intersegmental fold, hydro dorsum of the abdomen with numerous plain hairs. Around $16 \mathrm{~mm}$ in length.

\section{Arctopsyche irrorata (Banks, 1905):}

Larvae length 23-27 mm; head black, pale midventrally, with distinct pattern of pale spots dorsally and mostly confined to fronto-clypeus; thoracic nota with pale median line and mottled laterally. Larvae construct cylindrical portable cases, anal claw with stout apical hook, meta-notum entirely covered by sclerite, abdomen with ventrolateral rows of gills, tuft of long setae at anal proleg, genae ventrally, separating apotome into anterior and posterior parts or inconspicuous, genae of head capsule completely separated by single ventral apotome, most abdominal segments with long seta, ventral apotome narrowed.

\section{Family: Hydroptilidae}

Ochrotrichia tenuata (plate 13) (Blickle \& Denning, 1977):

Larvae up to $5.5 \mathrm{~mm}$; abdomen laterally compressed; thoracic legs the same length, foretibia with posteroventral lobe; without anal gills; cylindrical portable cases, consisting of 2 silk valves covered with sand. Meta-notum covered by sclerite, sometimes pigmented and sometimes with a transverse anteriorly positioned membranous area. Abdomen without branched gills or tuft of setae, anal proleg not projecting from the abdomen. Found in many different types of streams and rivers, on rocks in algal mats and in moss in current.

\section{Molecular Analysis}

The identification of aquatic insects based on DNA analysis shows high diversity of species and provides much promise as a method for taxonomic study and as a basis for phylogenetic analysis. It is becoming increasingly popular because these insects are excellent indicators of aquatic environmental quality [32,33].

In the present study, the phylogeny of 30 aquatic insect's larvae in the Greater Zab River, was analyzed by using two molecular markers as cytochrome c oxidase subunit I (Cox1) sequences and 16S RNA Figure 2.

The phylogenetic analysis based on barcode region of the mitochondrial DNA cytochrome c oxidase subunit I sequence ranging 650-660 bp were recovered revealed grouping of five main clades. The first clade, Baetis alpinus and Baetis braaschi are in the same sub-branch with the bootstrap value of $25 \%$, because of differences of environmental factors as [32,34] stated that the environment of the river changes dramatically and hierarchically along its course and the cross-section of a river has a very uneven and diverse habitat on a microhabitat scale.

While, Baetis noa, Serratella ignita, Leuctra hippopodias and Anapos kugleri are single clad (II, III, IV and IIV) respectively, because they belonged to different orders and families. In agreement, [35] determined the monophyly of the families Heptageniidae, Baetidae, and Ephemerellidae. Also, [36] endorsed there was no significant Bayesian or parsimony support for the monophyly of the eastern group of Leuctra hippos.

Whereas; phylogenetic analysis based on ribosomal RNA nucleotide sequence revealed grouping of four (IV) main clades as shown in Figure 3. The first clade (I) includes Maccaffertium meririvulanum and Leuctra inermis at bootstrap 48\%. In a study, [37] showed phylogenetic inference of Leuctra inermis and suggested sister taxon relationships between morphologically similar species because of similarity in morphological characters and linked in geographical location of populations. The Clade II includes Orectochilus villosus at bootstrap 55\%. with clade one. Also, [38] recognized genus-group taxa of (Coleoptera: Carabidae) supported as monophyletic. While preveiusly, [39] showed that Orectochilus sp. was paraphyletic and mitochondrial COI gene as a useful molecular marker for Gyrinidae phylogenetic studies. In clade III, Ephemerella cornutus was a single clade. The clade IV at bootstrap 100\% includes Hydropsyche simulans and Baetis harrisoni. Recently, [40] confirmed that the results strongly supported the monophyly of the Caenidae, Heptageniidae, Isonychiidae and Vietnamellidae families. On the other hand, [41] found that the family Hydropsychidae was monophyletic based on mitochondrial cytochrome oxidase I ( 658 base pairs).

It was also endorsed by relatively high genetic distances to other species. Several studies of DNA barcoding highlighted the cases where this approach was found unsuitable for species identification $[42,43]$. However, the results obtained in the studies on mayflies show a close 


\section{Al-Nahrain Journal of Science}

ANJS, Vol.24 (4), December, 2021, pp. 68-78

correspondence between the morphologically defined species and the barcode clusters [23,44-47].

However, in this work, we are unable to identify all small larvae precisely at the species level but obtaining sequences from particular specimens. Thus, these results may be regarded to variations in sampling sites as habitat characteristics are very important aspects when considering

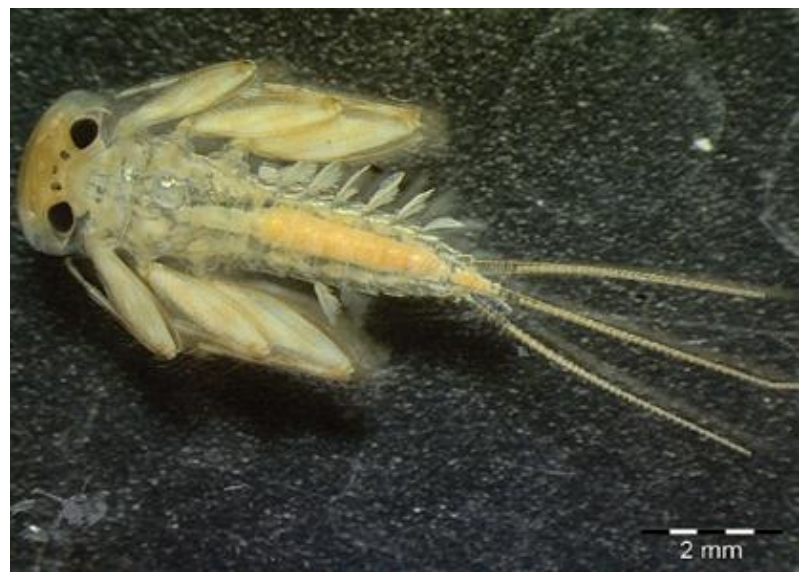

Plate 1. Ecdyonurus dispar.

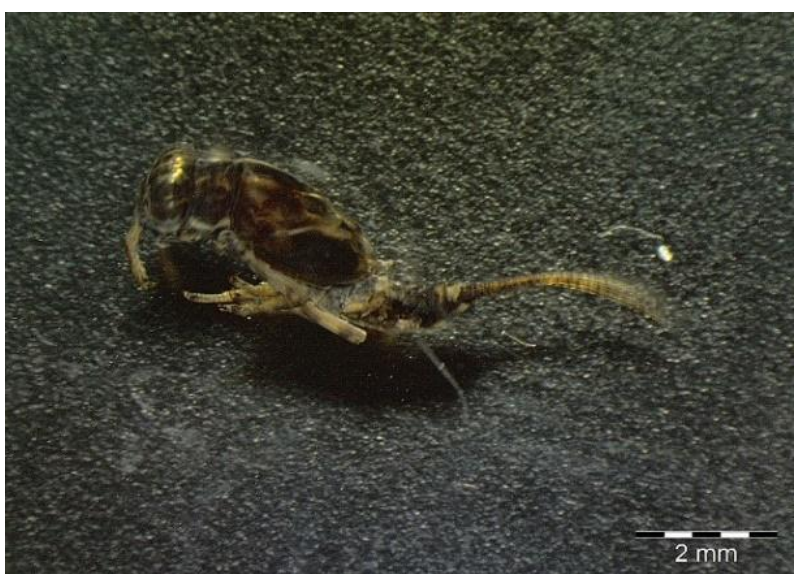

Plate 3. Seratella ignita.

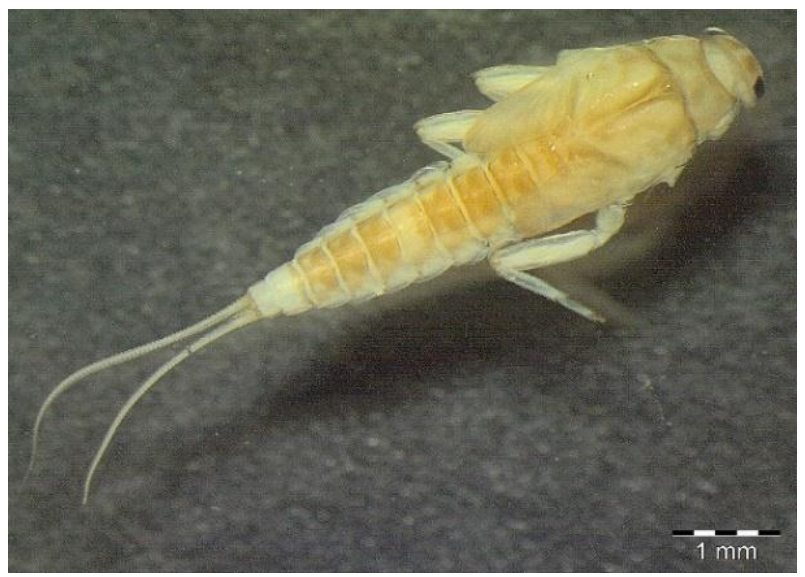

Plate 5. Iswaeon anoka. species distribution, as agreement with Heino and de Mendoza [48].

Overall, our findings suggest that DNA barcoding provides an excellent foundation for macroinvertebrate species identification (including insects) and offers new insight on local biodiversity assessment.

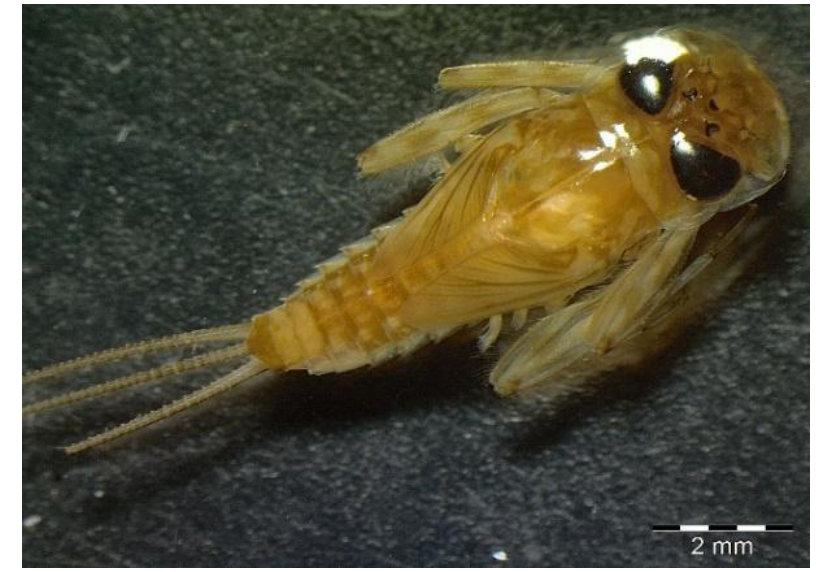

Plate 2. Stenonema femoratum.

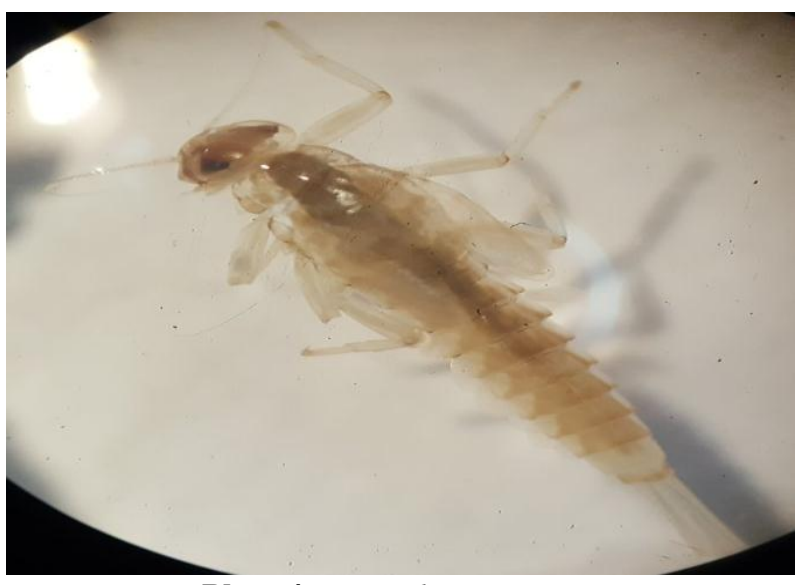

Plate 4. Baetis harrisoni.

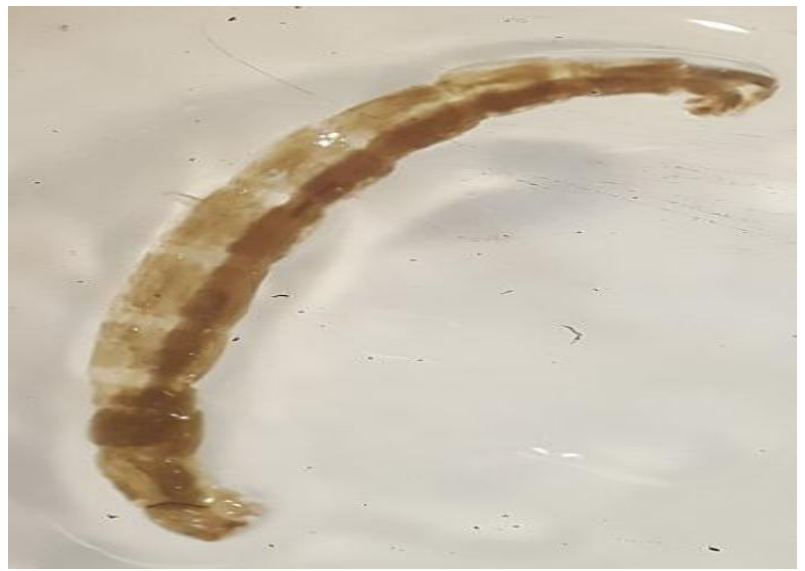

Plate 6. Simulium venustum. 


\section{Al-Nahrain Journal of Science}

ANJS, Vol.24 (4), December, 2021, pp. 68-78

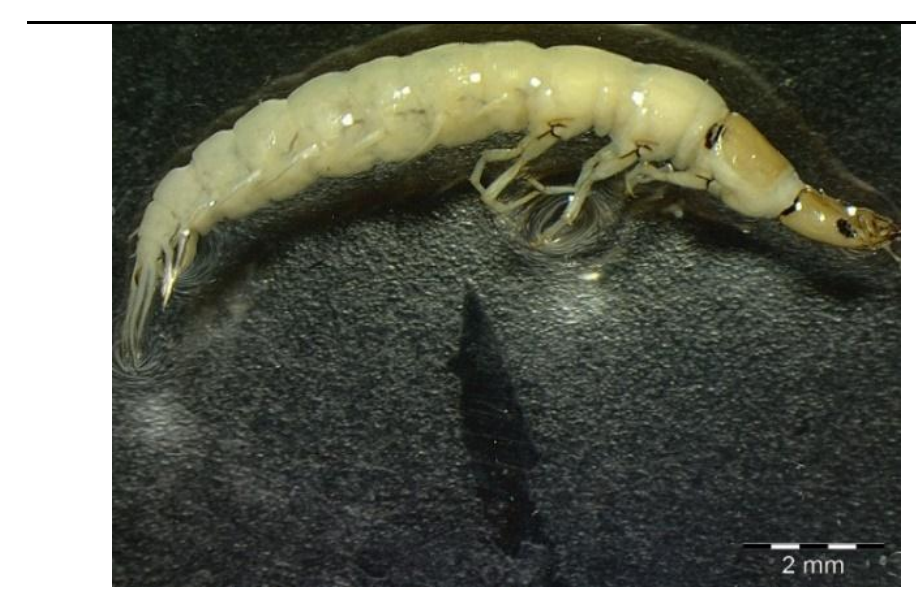

Plate 7. Orectochilus villosus.

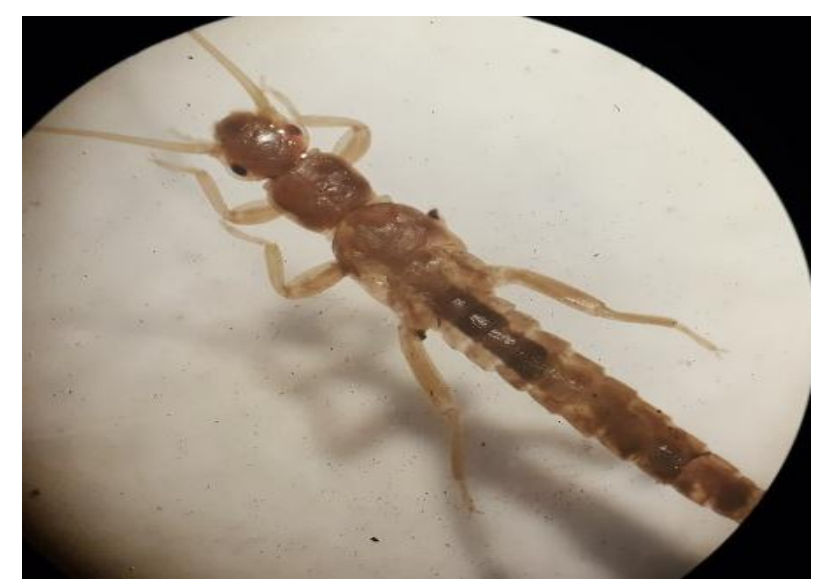

Plate 9. Leuctra hippopoides.



Plate 11. Lestes inaequalis.

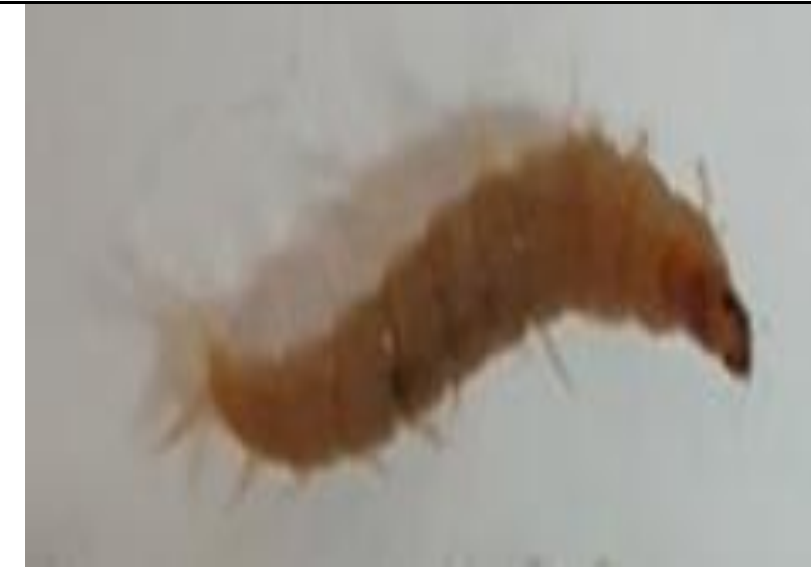

Plate 8. Nigrania serricarnis.

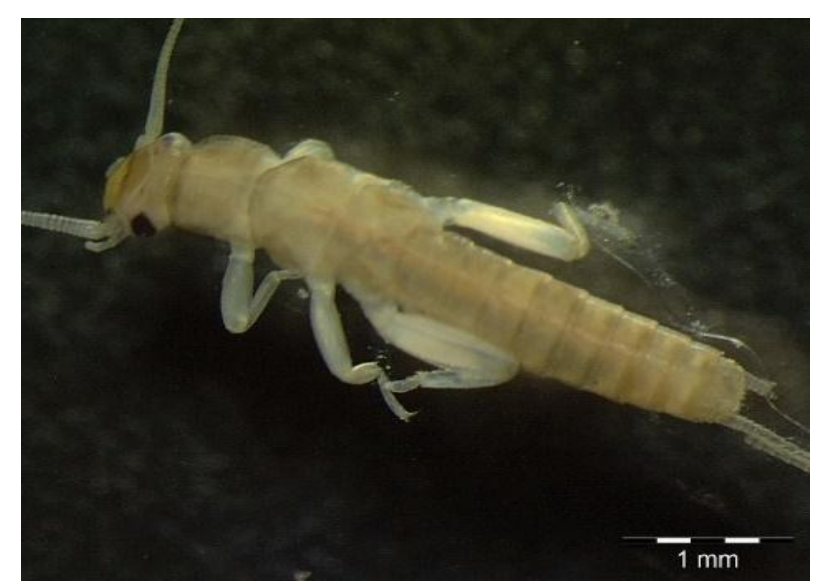

Plate 10. Leuctra inermis.

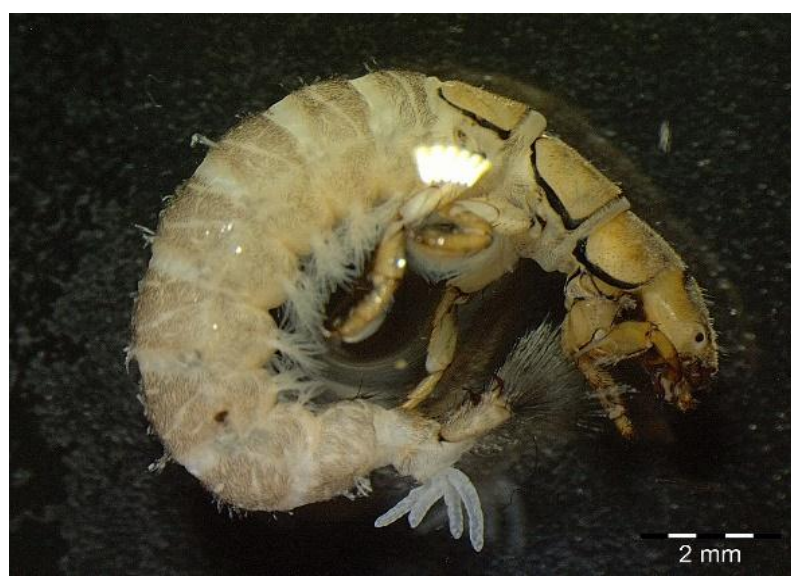

Plate 12. Hydropsyche simulans. 


\section{Al-Nahrain Journal of Science}

ANJS, Vol.24 (4), December, 2021, pp. 68-78
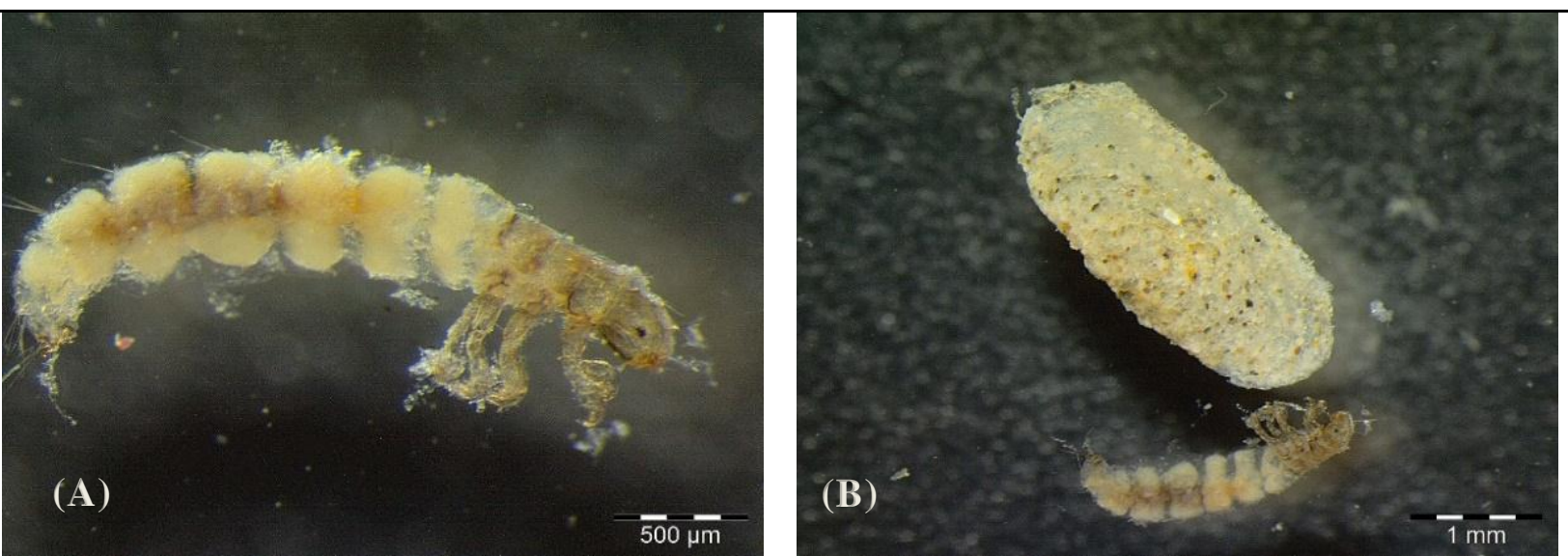

Plate 13. Ochrotrichia tenuata (A) whole body; (B) cylindrical portable cases.

Table 1. Show Coordination of studied locations.

\begin{tabular}{||c|c|c|c|c||}
\hline Site & Location & Latitude & Longitude & Elevation \\
\hline \hline 1 & Ava sheen & $3701^{\prime} 05 \mathrm{~N}$ & $43950^{\prime} 09 \mathrm{E}$ & 550 \\
\hline 2 & Sheladzae & $3701^{\prime} 25 \mathrm{~N}$ & 43 95'36 E & 570 \\
\hline 3 & Ble & $3692^{\prime} 15 \mathrm{~N}$ & $4403^{\prime} 06 \mathrm{E}$ & 477 \\
\hline 4 & Rezan & $36900^{\prime} 33 \mathrm{~N}$ & $4408^{\prime} 26 \mathrm{E}$ & 446 \\
\hline 5 & Khalan & $3641^{\prime} 26 \mathrm{~N}$ & $4400^{\prime} 08 \mathrm{E}$ & 406 \\
\hline 6 & Qandel & $36939^{\prime} 23 \mathrm{~N}$ & $443^{\prime} 40 \mathrm{E}$ & 375 \\
\hline
\end{tabular}

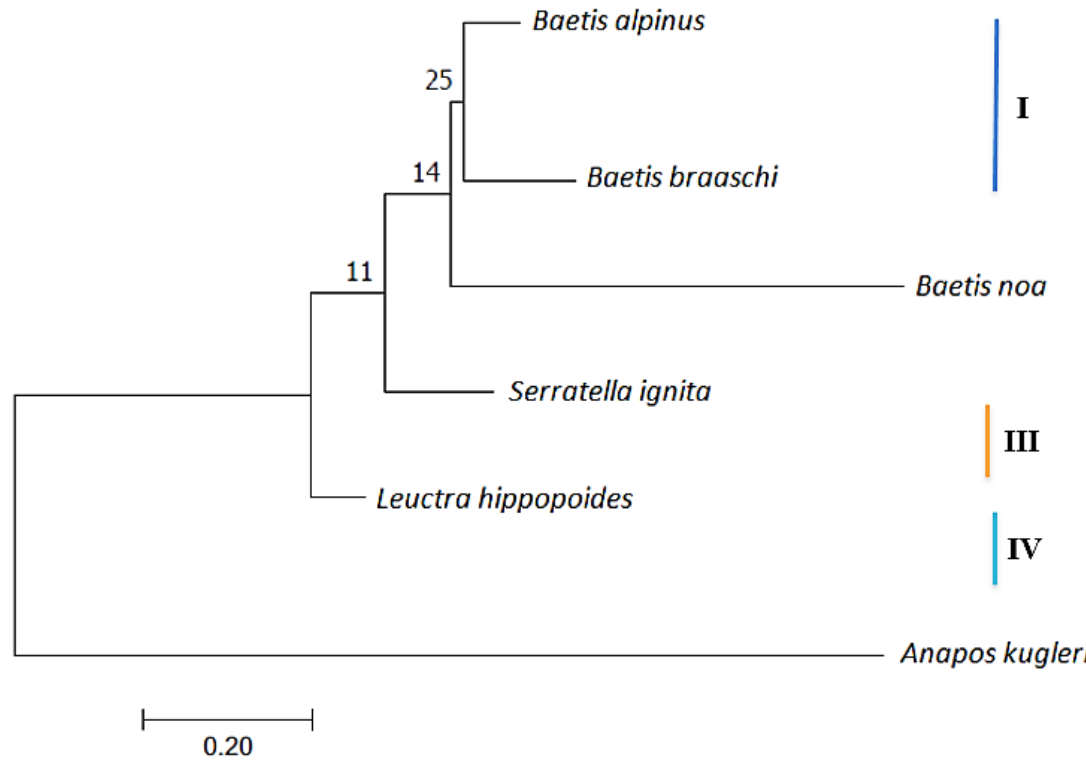

Figure 2: Molecular Phylogenetic analysis of COI by Maximum Likelihood method

The evolutionary history was inferred by using the Maximum Likelihood method based on the Tamura-Nei model (1). The tree with the highest log likelihood $(-4214.58)$ is shown. The percentage of trees in which the associated taxa clustered together is shown next to the branches. Initial tree(s) for the heuristic search were obtained automatically by applying Neighbor-Join and BioNJ algorithms to a matrix of pairwise distances estimated using the Maximum Composite Likelihood
(MCL) approach, and then selecting the topology with superior log likelihood value. The tree is drawn to scale, with branch lengths measured in the number of substitutions per site. The analysis involved 8 nucleotide sequences. Codon positions included were $1 \mathrm{st}+2 \mathrm{nd}+3 \mathrm{rd}+$ Noncoding. All positions containing gaps and missing data were eliminated. There was a total of 625 positions in the final dataset. Evolutionary analyses were conducted in MEGA7 (2). 


\section{Al-Nahrain Journal of Science}

ANJS, Vol.24 (4), December, 2021, pp. 68-78

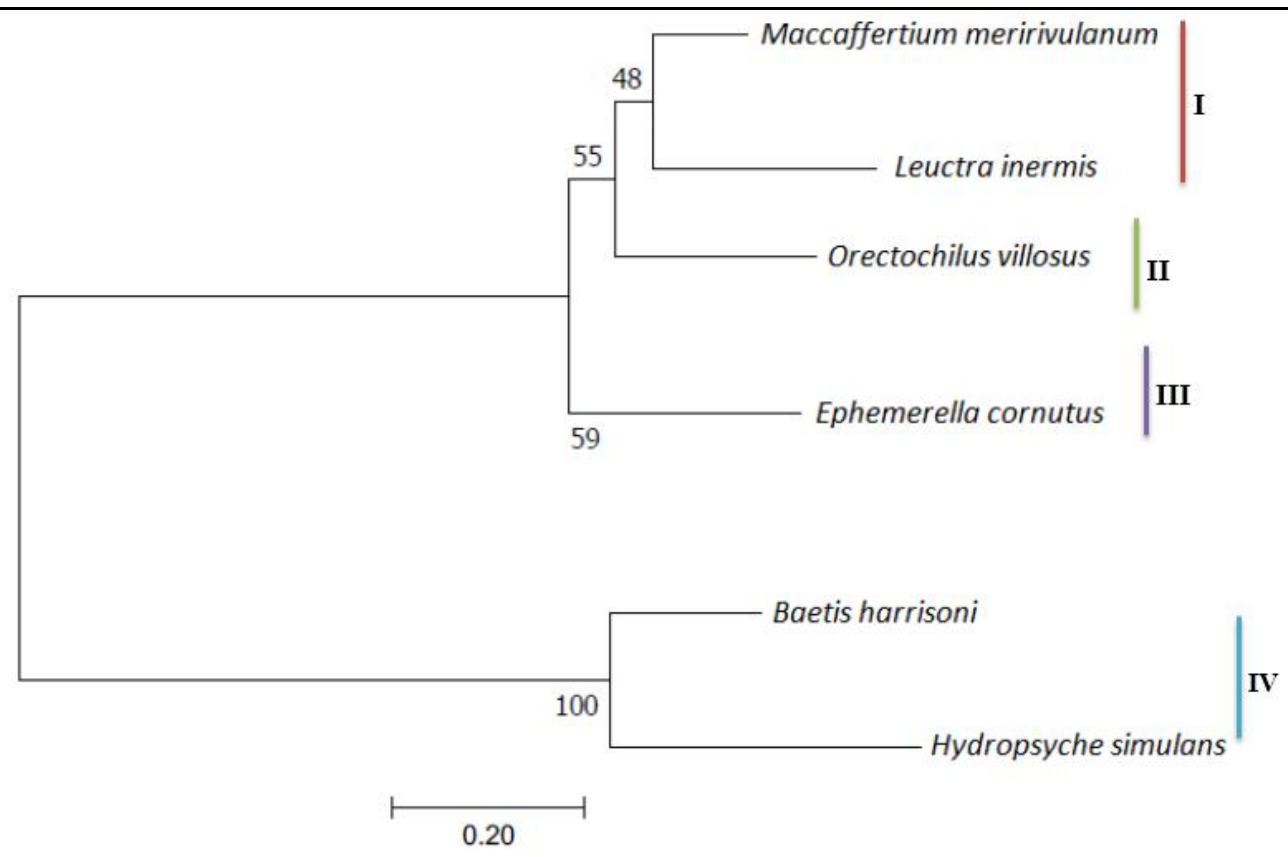

Figure 3. Shows Molecular Phylogenetic analysis of 16S RNA by Maximum Likelihood method.

The evolutionary history was inferred by using the Maximum Likelihood method based on the Tamura-Nei model (1). The tree with the highest log likelihood $(-3087.57)$ is shown. The percentage of trees in which the associated taxa clustered together is shown next to the branches. Initial tree(s) for the heuristic search were obtained automatically by applying Neighbor-Join and BioNJ algorithms to a matrix of pairwise distances estimated using the Maximum Composite Likelihood (MCL) approach, and then selecting the topology with superior log likelihood value. The tree is drawn to scale, with branch lengths measured in the number of substitutions per site. The analysis involved 10 nucleotide sequences. Codon positions included were $1^{\text {st }}+2^{\text {nd }}+3^{\text {rd }}+$ Noncoding. All positions containing gaps and missing data were eliminated. There was a total of 367 positions in the final dataset. Evolutionary analyses were conducted in MEGA7 (2).

\section{References}

[1] Foomani, A.; Gholizadeh, M.; Harsij, M. and Salavatian, S. M.; "River health assessment using macroinvertebrates and water quality parameters: A case of the Shanbeh-Bazar River". Anzali Wetland. Iran. Iranian Journal of Fisheries Sciences, 19 (5): 2274-2292, 2020.

[2] Narangarvuu, D.; Hsu, C.-B.; Shieh, S.-H.; Wu, F.-C. and Yang, P.-S.; "Macroinvertebrate assemblage patterns as indicators of water quality in the Xindian watershed". Taiwan. Journal of Asia-Pacific Entomology, 17: 505-513, 2014.

[3] Muralidharan, M.; Selvakumar, C.; Sundar, S. and Raja, M.; "Macroinvertebrates as potential indicators of environmental quality". Indian Journal of Biotechnology, 1: 23-28, 2010.

[4] Hussain, Q. A.; "Macroinvertebrates in streams: A review of some ecological factors". International Journal of Fisheries and Aquaculture, 4: 114-123.

[5] Hellmann, J. K.; Erikson, J. S. and Queenborough, S. A. 2015. "Evaluating macroinvertebrate community shifts in the confluence of freestone and limestone streams". Journal of limnology, 74, 2012.

[6] Bertoli, M.; Azzoni, M. and Pizzul, E.; "A Comparison Between Biomonitoring Methods for the Analysis of Macrobenthic Invertebrate Communities in Different River Types of Friuli Venezia Giulia/Differenti Strategie Di Monitoraggio Per Lo Studio Delle Comunità Macrozoobentoniche in Diverse Tipologie Fluviali Del Friuli Venezia Giulia". Annales: Series Historia Naturalis. Scientific and Research Center of the Republic of Slovenia, 139, 2014.

[7] Fierro, P.; Valdovinos, C.; Arismendi, I.; Díaz, G.; JaraFlores, A.; Habit, E. and Vargas-Chacoff, L.; "Examining the influence of human stressors on benthic algae, macroinvertebrate, and fish assemblages in Mediterranean streams of Chile". Science of The Total Environment, 686: 26-37, 2019.

[8] Morinière, J.; Hendrich, L.; Balke, M.; Beermann, A. J.; König, T.; Hess, M.; Koch, S.; Müller, R.; Leese, F. and Hebert, P. D.; "A DNA barcode library for Germany' s mayflies, stoneflies and caddisflies (Ephemeroptera, Plecoptera and Trichoptera)". Molecular Ecology Resources, 17: 1293-1307, 2017.

[9] Monaghan, M. T.; Balke, M.; Gregory, T. R. and Vogler, A. P.; "DNA-based species delineation in tropical beetles using mitochondrial and nuclear 


\section{Al-Nahrain Journal of Science}

ANJS, Vol.24 (4), December, 2021, pp. 68-78

markers. Philosophical Transactions of the Royal Society B". Biological Sciences, 360: 1925-1933, 2005.

[10] Molina, C. I.; Gibon, F. M.; Dominguez, E.; Pape, T. and Ronsted, N.; "Associating immatures and adults of aquatic insects using DNA barcoding in high Andean streams". Ecología en Bolivia. 52(2): 88-99, 2017.

[11] Abbasi, T. and Abbasi, S. A.; "Water quality indices", Elsevier, 2012.

[12] Ismaiel, I. A.; Bird, G.; Mcdonald, M. A.; Perkins, W. T. and Jones, T. G.; "Establishment of background water quality conditions in the Great Zab River catchment: influence of geogenic and anthropogenic controls on developing a baseline for water quality assessment and resource management". Environmental Earth Sciences, 77, 50, 2018.

[13] Lind, O. T.; "Handbook of common methods in limnology". The CV Mosley Company, 1979.

[14] Edmonson, W. T.; "Freshwater biology". USA, ohn Wiely and Sons, Inc., 1959.

[15] Bolton, M. J.; "Ohio EPA supplemental keys to the larval Chironomidae (Diptera) of Ohio and Ohio Chironomidae checklist". Ohio Environmental Protection Agency, Groveport, 2007.

[16] Merritt, R.; Cummins, K. and Berg, M.; "An introduction to the aquatic insects of North America". $4^{\text {th }}$ edn. Kendall. Hunt Publishing Company, Dubuque, 2008.

[17] Madden, C. P.; "Key to genera of larvae of Australian Chironomidae (Diptera). Museum Victoria Science Reports", 2010.

[18] Beaty, S.; "The Ephemeroptera of North Carolina: A biologist's handbook with standard taxonomic effort levels. Raleigh: Biological Assessment Unit, Division of Water Quality". North Carolina Department of Environment and Natural Resources, 2011.

[19] Bauernfeind, E. and Soldan, T.; "The Mayflies of Europe (Ephemeroptera)". Brill.; 2012.

[20] Beaty, S.; "The Plecoptera of North Carolina: A Biologist's Handbook for the Identification of Stonefly Nymphs with Standard Taxonomic Effort Levels". Version 4.1. North Carolina Department of Environmental Quality, Division of Water Resources, Biological Assessment Branch. Raleigh, North Carolina. iv+ 91 pp. North Carolina Department of Environmental Quality, Division of water, 2015.

[21] Yanai, Z.; Gattolliat, J.-L. and Dorchin, N.; "Taxonomy of Baetis Leach in Israel (Ephemeroptera, Baetidae)". ZooKeys, 45, 2018.

[22] Doyl, J. and Doyle, J.; "Isolation of plant DNA from fresh tissue". Focus, 12: 13-15, 1990.

[23] Ball, S. L.; Hebert, P. D.; Burian, S. K. and Webb, J. M.; "Biological identifications of mayflies (Ephemeroptera) using DNA barcodes". Journal of the North American Benthological Society. 24: 508-524, 2005.

[24] Flomer, O.; "DNA primers for amplification of mitochondrial cytochrome $\mathrm{c}$ oxidase subunit I from diverse metazoan invertebrates". Molecular marine biology and biotechnology, 3: 294-299, 1994.

[25] Ogden, T. H. and Whiting, M. F.; "Phylogeny of Ephemeroptera (mayflies) based on molecular evidence". Molecular phylogenetics and evolution, 37: 625-643, 2005.

[26] Ossa-López, P. A.; Camargo-Mathias, M. I. and Rivera-Páez, F. A.; "Andesiops peruvianus (Ephemeroptera: Baetidae): a species complex based on molecular markers and morphology". Hydrobiologia, 805: 351- 364, 2018.

[27] Thorp, J. H. and Rogers, D. C.; "Field guide to freshwater invertebrates of North America". Academic Press, 2010.

[28] Jacobus, L. M.; Macadam, C. R. and Sartori, M.; "Mayflies (Ephemeroptera) and Their Contributions to Ecosystem Services". Insects, 10, 170, 2019.

[29] Ali, L. A.; "A study of macroinvertebrates community in the middle sector of Greater Zab River". Iraq. Ph.D. Thesis, University of Baghdad, Iraq, 2006.

[30] Shekha, Y. A.; "A Study of Benthic Macroinvertebrate Community in the Lower Part of Greater Zab River Near Guwer Subdistrict". Rafidain journal of science, 22: 33-45, 2011.

[31] Hanna, N. S. and Shekha, Y. A.; "Using aquatic insects in water quality assessment of some branches of Greater Zab River within Erbil city, Iraqi Kurdistan Region". American International Journal of Research in Formal, Applied \& Natural Sciences, 11(1): 18-22, 2015.

[32] Jo, J. and Tojo, K.; "Molecular analyses of the genus Drunella (Ephemeroptera: Ephemerellidae) in the East Asian region". Limnology, 1-12.

[33] Suh, K. I.; Hwang, J. M.; Bae, Y. J. and Kang, J. H.; "Comprehensive DNA barcodes for species identification and discovery of cryptic diversity in mayfly larvae from South Korea: Implications for freshwater ecosystem biomonitoring". Entomological research, 49: 46-54, 2019.

[34] Dijkstra, K.-D. B.; Monaghan, M. T. and Pauls, S. U.; "Freshwater biodiversity and aquatic insect diversification". Annual review of entomology, 59: 143-163, 2014.

[35] Gao, X.-Y.; Zhang, S.-S.; Zhang, L.-P.; Yu, D.-N.; Zhang, J.-Y. and Cheng, H.-Y.; "The complete mitochondrial genome of Epeorus herklotsi (Ephemeroptera: Heptageniidae) and its phylogeny". Mitochondrial DNA Part B, 3: 303-304, 2018.

[36] Boumans, L.; Hogner, S.; Brittain, J. and Johnsen, A.; "Ecological speciation by temporal isolation in a population of the stonefly Leuctra hippopus (Plecoptera, Leuctridae)". Ecology and evolution, 7: 1635-1649, 2017.

[37] Vitecek, S.; Vincon, G.; Graf, W. and Pauls, S. U.; "High cryptic diversity in aquatic insects: an integrative approach to study the enigmatic Leuctra 


\section{Al-Nahrain Journal of Science}

ANJS, Vol.24 (4), December, 2021, pp. 68-78

inermis species group (Plecoptera)". Arthropod Systematics \& Phylogeny, 75: 497-521, 2017.

[38] Kavanaugh, D.; Maddison, D.; Simison, B.; Schoville, S.; Schmidt, J. and Faille, A.; "Phylogeny of the supertribe Nebriitae (Coleoptera: Carabidae) based on analyses of molecular sequence data--some surprises". ARPHA Conference Abstracts. Pensoft Publishers, e37156, 2019.

[39] Xi, Q.-Y.; Deng, R.-Q.; Wang, J.-W.; Jia, F.-L. and Wang, X.-Z.; "Phylogeny of Gyrinidae and Hydradephaga (Insecta: Coleoptera) Based on CO I Gene: A Case Study Using codon-partitioning Schemes in Phylogenetic Tree Reconstruction". 昆蟲 學報, 51: 166-181, 2008.

[40] Xu, X.-D.; Jia, Y.-Y.; Dai, X.-Y.; Ma, J.-L.; Storey, K. B.; Zhang, J.-Y. and Yu, D.-N.; "The mitochondrial genome of Caenis sp.(Ephemeroptera: Caenidae) from Fujian and the phylogeny of Caenidae within Ephemeroptera". Mitochondrial DNA Part B, 5:192$193,2020$.

[41] Uy, C. J. C.; Kang, J. H.; Morse, J. C. and Bae, Y. J.; "Phylogeny of Macronematinae (Trichoptera: Hydropsychidae) based on molecular and morphological analyses". The Canadian Entomologist, 151: 696-716, 2019.

[42] Meier, R.; Shiyang, K.; Vaidya, G. and Ng, P. K.; "DNA barcoding and taxonomy in Diptera: a tale of high intraspecific variability and low identification success". Systematic biology, 55: 715-728, 2006.

[43] Hrivniak, L'; Sroka, P.; Türkmen, G.; Godunko, R. J. and Kazanci, N.; "A new Epeorus (Caucasiron)(Ephemeroptera: Heptageniidae) species from Turkey based on molecular and morphological evidence". Zootaxa, 4550:58-70, 2019.

[44] Webb, J.; Sun, L.; Mccafferty, W. and Ferris, V.; "A new species and new synonym in Heptagenia Walsh (Ephemeroptera: Heptageniidae: Heptageniinae) based on molecular and morphological evidence". Journal of Insect Science, 7.

[45] Alexander, L. C.; Delion, M.; Hawthorne, D. J.; Lamp, W. O. and Funk, D. H.; "Mitochondrial lineages and DNA barcoding of closely related species in the mayfly genus Ephemerella (Ephemeroptera: Ephemerellidae)". Journal of the North American Benthological Society, 28: 584-595, 2009.

[46] Zhou, X.; Jacobus, L. M.; Dewalt, R. E.; Adamowicz, S. J. and Hebert, P. D.; "Ephemeroptera, Plecoptera, and Trichoptera fauna of Churchill (Manitoba, Canada): insights into biodiversity patterns from DNA barcoding". Journal of the North American Benthological Society, 29: 814-837, 2010.

[47] Webb, J. M.; Jacobus, L. M.; Funk, D. H.; Zhou, X.; Kondratieff, B.; Geraci, C. J.; Dewalt, R. E.; Baird, D. J.; Richard, B. and Phillips, I.; "A DNA barcode library for North American Ephemeroptera: progress and prospects". PloS one, 7, e38063, 2012.
[48] Heino, J. and De Mendoza, G.; "Predictability of stream insect distributions is dependent on niche position, but not on biological traits or taxonomic relatedness of species". Ecography, 39: 1216-1226, 2016. 